\title{
IMPLIKASI PERATURAN KERANGKA KERJA MANAJEMEN KEUANGAN PUBLIK PADA PENYEDIAAN LAYANAN : REFLEKSI MAJELIS DISTRIK NEGARA GHANA
}

\author{
Fahri Juarsa Muhammad ${ }^{1}$, Herijanto Bekti ${ }^{2}$, Yogi Suprayogi Sugandi ${ }^{3}$ \\ 1,2,3 Program Studi Administrasi Publik, FISIP, Universitas Padjadjaran \\ Email: fahri14001@mail.unpad.ac.id, herijantobekti@mail.unpad.ac.id, \\ y.suprayogi16@gmail.com
}

Article Histori:

Submited: 04/01/2020

Editing: 28/04/2020

Publish: 30/04/2020

\section{Abstract}

Public Financial Management a set of laws, rules and standards is an important part of regulating the systems and processes used by each sovereign state and local government, in order to mobilize revenue, allocate public funds, conduct public spending, and budget audits. The purpose of public financial management itself is to increase efficiency and transparency in the use of public resources and eliminate the inefficiency of public resources. The regulatory framework for Public Financial Management is able to carry out analytical and critical practices in helping to facilitate services efficiently and effectively. This article uses a qualitative method with a descriptive approach as to describe or analyze a research result but is not used to make a broader conclusion. Analysis and Discussion The Government of Ghana is aware that there are regulations governing the budgeting, although some of them do not understand and study these documents comprehensively. The regulatory framework governing fund management influences service delivery. In conclusion, the regulatory framework explains how public budgets are used to provide better services. The regulation is designed with the aim of helping to reduce budget waste and prevent corruption.

Keyword: Regulatory, Public Financial Management, Services Delivery.

\section{PENDAHULUAN}

Kebutuhan akan peraturan dalam konteks suatu kerja yang digunakan untuk dapat mengoperasikan berbagai sistem menjadi sebuah hal penting dalam semua interaksi manusia, baik tingkatan pribadi maupun tingkat organisasi. Manajemen
Keuangan Publik merupakan seperangkat hukum, aturan, dan standar menjadi bagian penting dalam mengatur sistem serta proses yang digunakan setiap negara kedaulatan dan pemerintah daerah, agar dapat memobilisasi pendapatan, mengalokasikan dana publik, melakukan belanja publik, 
serta audit anggaran (ICPAK, 2017). Berdasarkan pendapat dari ICPAK bahwa tujuan manajemen keuangan publik sendiri yaitu meningkatkan efisiensi dan transparansi dalam penggunaan sumber daya publik serta menghilangkan inefisiensi sumber daya publik. (Jordaan \& Fourie, 2007) menemukan indikasi yang menyatakan bahwa interaksi terhadap beberapa komponen Manajemen Keuangan Publik berada diruang lingkup mereka sendiri serta adanya pemberian pelayanan yang memerlukan peraturan dan pengawasan.

(Lynn et al., 2001) berpendapat bahwa jika sebuah peraturan kerangka kerja terdiri dari berbagai isu-isu pemerintahan seperti hukum, aturan, keputusan pengadilan, dan praktik administrasi sebagai bentuk praktik Manajemen Keuangan Publik juga adanya batasan dalam hal memberikan sebuah pelayanan publik. Pendapat yang lain dengan argument yang sama yaitu (Ohman, 2012) mengatakan bahwa sebuah peraturan kerangka kerja yang bertumpu pada hukum mendeskripsikan adanya syarat hukum yang harus dipenuhi. Ohman menambahkan bahwa sebuah syarat hukum ini harus dilengkapi dengan adanya kebijakan, tolak ukur, pedoman serta sanksi terhadap yang melanggar sebuah ketetapan. Oleh karena itu, berbagai penjelasan diatas dapat disimpulkan bahwa perundangundangan, pedoman, peraturan, kebijakan, tolak ukur, serta hukuman terhadap pelanggar adalah hal terpentingan dalam menyusun peraturan terhadap kerangka kerja Manajemen Keuangan Publik.

Regulasi kerangka kerja Manajemen Keuangan Publik mampu menjalankan praktik analisis serta kritis dalam membantu memfasilitasi pelayanan secara efisien dan efektif. kebutuhan untuk segi pengelolaan sumber daya dapat ditangani secara ketat, mengandung nilai keterbukaan, menciptakan keadilan secara merata, kesetaraan, transparansi, akuntabilitas, kejujuran, integritas, serta kredibilitas (Khalil and Adelabu, 2012).

Dalam studi kasus khusus mengenai majelis wilayah, (Lee and Johnson, 1998) mengatakan bahwa sebuah prinsip dasar terhadap pengawasan atau control kepada mereka dalam hal ini lembaga eksekutif yang membelanjakan anggaran publik tidak bisa merangkap dalam menjalankan fungsi pengawasan dan audit. Karena eksekutif sebagai lembaga pemerintah yang berwenang atas kekuasaan perencanaan secara administratif yang membuat fungsi control atau pengawasan diberikan kepada pihak legislatif. (Santiso, 2015) menambakan bahwa adanya peran legislatif yang menjadi dasar regulasi kerangka kerja, terutama adanya keterlibatan dalam proses penganggaran serta proses audit dalam proyek pembangunan dan pemberian pelayanan oleh unit pemerintah nasional dengan asas desentralisasi.

Sistem Informasi Manajemen Keuangan Terpadu (IFMIS), dapat dianggap sebagai jawaban atas permasalahan kurangnya data yang dapat diandalkan, tepat waktu serta pengawasan keuangan yang dinilai buruk. Berdasarkan pendapat (Hendriks, 2013) IFMIS dapat meningkatkan manajemen sektor publik dengan cara memberikan informasi keuangan secara tepat waktu kepada para manajer dalam rangka peningkatkan kemampuan atas pengambilan keputusan yang akan mereka lakukan.

Pendekatan Manajemen Keuangan Publik membutuhkan check and balance diantaranya adalah pengembangan kapasitas. Untuk membangun kapasitas dalam Manajemen Keuangan Publik, perlu adanya penekankan yang dilakukan pada tingkatan individu, organisasi, serta 
kelembagaan, yang bertujuan meningkatkan kinerja fungsi yang efisien. Contohnya, Pengawasan yang dibutuhkan oleh berbagai badan yang terkait seperti ombudsman serta badan negara lainnya yang dapat menerapkan sanksi seperti pengadilan dan badan audit atas penyalahgunaan kekuasaan mereka dalam keuangan publik. dalam penganggaran wajib disajikan kepada publik, disaat yang bersamaan pemerintah dapat melihat struktur yang harus diperbaiki dalam sistem pembayaran, sistem akuntansi serta sistem audit. (Kopits, 2011) lebih lanjut menjelaskan bahwa adanya pengawasan yang aktif dilakukan lembaga parlemen, serta posisi auditor harus independen dengan dilindungi oleh konstitusi.

Keinginan pihak pemerintah untuk mengalihkan struktur kekuasaan yang desentralisasi serta tingkat otonomi didalam administrasi publik dan pemerintah dapat meningkatkan efektivitas regulasi Manajemen Keuangan Publik. Elemen yang dapat mempengaruhi efektivitas kerangka peraturan menurut (Santiso, 2015) yaitu sistem politik, kekuatan konstitusional untuk mengubah serta merancang anggaran, dinamika partai politik, anggaran legislatif, kapasitas penelitian, serta informasi yang dapat diakses secara relevan.

Negara - negara Afrika yang terjadi masa lalu bergejolak dengan adanya permasalahan seperti korupsi, pengelolaan anggaran yang tidak dilakukan dengan benar, adanya penekanan pada pemerintah oleh warga negara dan mitra pembangunan untuk meningkatkan akuntabilitas, serta memberikan pelayanan yang maksimal merupakan wujud dalam reformasi Manajemen Keuangan Publik. Dalam peraturan kerangka kerja Manajemen Keuangan Publik, sebagian besar negara di Afrika telah menetapkan berbagai tindakan dalam mewujudkan Manajemen Keuangan Publik dengan pedoman yang kuat dan jelas. Seperti di Negara Ghana, mereka memiliki kerangka kerja legislatif yang kuat dalam manajemen keuangan publik. Namun, sebagai bagian dari era reformasi, tentu perubahan undang-undang serta regulasi yang berkaitan dengan Manajemen Keuangan Publik diperbarui dalam beberapa tahun terakhir. Undang-undang dan peraturan tersebut termasuk UndangUndang Administrasi Keuangan (FAA) tahun 2003 serta Undang-Undang Umum Auditor tahun 2000.

Kerangka kerja badan legislatif dan peraturan di negara Ghana menetapkan akuntabilitas struktur anggaran dasar serta pengawasan yang dilakukan oleh Parlemen serta penjelasan terkait tentang kekuasaan dan tugas untuk para stakeholder yang memiliki peran penting, termasuk Kementerian Keuangan dan Perencanaan Ekonomi (Kemenkeu) dan Anggota Legislatif (District Assemblies). Ada juga Undang-Undang Pengadaan Publik (2003) yang membentuk Dewan Pengadaan Publik dalam merancang berbagai regulasi secara administratif dan kelembagaan dalam hal pengadaan publik yang dilakukan secara adil, transparan dan tidak diskriminatif. Selanjutnya, regulasi tentang UndangUndang Badan Audit Internal (2003), yang membentuk Badan Audit Internal dengan bertujuan dapat mengkoordinasikan, memfasilitasi serta memberikan jaminan kualitas pada bagian audit internal di setiap Kementerian, Departemen, dan Lembaga Majelis Distrik.

Dalam mengimplementasikan suatu regulasi, keinginan nyata dari pihak pemerintah agar membentuk struktur kekuasaan yang terdesentralisasi agar dapat terciptanya efektivitas peraturan Manajemen Keuangan Publik dalam memberikan pelayanan yang baik. Sementara desentralisasi sebagai solusi atas permasalahan dalam ketidakadilan dan reformasi regulasi Manajemen Keuangan 
Publik bergerak kearah yang salah. (Jonah, 2014) berpendapat bahwa distribusi dan akses akan sebuah ketidakadilan masih terjadi di Negara Ghana meskipun ada upaya desentralisasi melalui Majelis Distrik selama 24 tahun terakhir.

Adanya teori sistem, kerangka kerja peraturan Manajemen Keuangan Publik dianggap memiliki peran interaktif serta berpengaruh atas aspek Manajemen Keuangan Publik lainnya seperti penganggaran, pendapatan serta pembiayaan. Motivasi pembiayaan terkait dorongan kepada agen yang bertugas dalam bidang penagihan pendapatan serta petugas pengadaan untuk berhenti melakukan kecurangan atau bekerjasama dengan para pedagang maupun supplier. Dalam hal koordinasi dan pengendalian pembiayaan tersebut indikasinya atas perselisihan seperti pemogokan oleh karyawan atau penolakan untuk memasok barang karena pembayaran yang tidak tepat waktu seperti yang dikemukakan oleh (Buertey et al., 2014). Akibatnya, peraturan kerangka kerja Manajemen Keuangan Publik masih belum mampu mengatasi masalah seperti itu di banyak negara berkembang seperti Ghana.

Masalah empiris regulasi kerangka kerja Public Financial Management diungkapkan dalam beberapa literature. Seperti contoh yang diberikan oleh (Zhou, 2012) melakukan penelitian yang bertujuan untuk menetapkan peran kerangka hukum dan kelembagaan dalam meningkatkan efisiensi administrasi publik. Penelitian ini dilakukan dengan menggunakan analisis dokumen dan wawancara dengan para ahli hukum senior dari kantor Ombudsman. Dokumen-dokumen yang dianalisis termasuk Peraturan Zimbabwe, Undangundang parlemen dan kebijakan hukum dan peraturan lainnya dari berbagai kementerian. Studi ini menetapkan bahwa meskipun Zimbabwe memiliki kerangka hukum dan kelembagaan yang luas, namun, faktor utama bukanlah keberadaan tetapi kepatuhan terhadap berbagai peraturan. Penelitian ini juga mengungkapkan bahwa sebagian besar lembaga yang memiliki mandat untuk mengatur pemerintah pusat serta pemerintah lainnya dengan struktur buruk yang dimiliki serta adanya berbagai permasalahan tentang sumber daya. Hal tersebut sebagian besar lembaga tidak efektif dalam meningkatkan pelayanan kepada masyarakat.

(Zhou, 2012) menjelaskan lebih lanjut terhadap penelitiannya bahwa administrasi keuangan publik di Zimbabwe berada di bawah tekanan dalam kerangka konstitusional dan hukum didalamnya. Lingkungan politik yang memburuk berdampak pada operasi eksekutif, legislatif dan peradilan. Dalam penelitian yang dilakukan oleh Zhou, (Moyo, 2011) mencatat beberapa hal penting yaitu penegakan administrasi juga dapat dikompromikan oleh kendala fiskal. Selanjutnya, penelitian ini menetapkan bahwa Kantor Pengawasan Keuangan dan Direktorat Jenderal Auditor dalam beberapa dekade secara umum dihadapkan pada kendala sumber daya yang serius. Sehingga, instansi terkait juga tidak memiliki kekuatan yang diperlukan untuk menegakkan disiplin eksekutif yang memmunculkan berbagai rekomendasi. Oleh karena itu, penelitian ini mengungkapkan bahwa penegakan hukum yang buruk menghambat peningkatan pelayanan kepada warga negara karena adanya kesalahan pengelolaan sumber daya.

Untuk mengetahui hubungan antara regulasi kerangka kerja dan pemberian pelayanan, (Prakash, 2015) melakukan penelitian pada pengaruh regulasi kerangka kerja serta kebijakan bertujuan memberikan pelayanan kesehatan. Tujuan dari penelitian ini adalah untuk menyelidiki regulasi yang 
didevolusikan pada sektor perawatan kesehatan di India dan membuat rekomendasi yang diperlukan dengantujuan peningkatan pelayanan kesehatan. Data yang dikumpulkan berasal dari data kualitatif yaitu pejabat dan staf pada rumah sakit umum negara bagian. Selanjutnya, survey dilakukan kepada pasien untuk menilai kualitas pelayanan. Regulasi yang ada mengindikasikan tertuju pada kerangka kerja kelembagaan secara sah yang diizinkan untuk menetapkan partisipasi kegiatan para pemangku kepentingan. Peraturan perundangundangan adalah aturan yang dapat ditegakkan secara hukum yang mengatur perilaku atau hasil yang diharapkan. Peraturan tersebut juga termasuk standar yang berfungsi sebagai tolok ukur tingkat kepatuhan, sanksi bagi yang tidak patuh dan stakeholder terkait dalam mengatur penegakkan aturan serta pemberian sanksi administratif.

Dalam Penelitian tersebut, (Prakash, 2015) menetapkan bahwa peraturan perundang-undangan dirumuskan oleh badan legislatif negara dan implementasinya melalui lembaga eksekutif yaitu kementerian, departemen, badan hukum dan instansi administrasi pemerintah. Selain itu, penelitian ini menemukan bahwa para pemangku kepentingan, seperti media, kelompok masyarakat dapat menjadi jembatan kesenjangan antara pemerintah dan warga negara dengan tujuan agar dapat melihat secara langsung berbagai tindakan kolektif yang telah dilakukan oleh pemerintah.

(Prakash, 2015) menunjukkan bahwa beberapa regulasi atau peraturan yang relevan sebagai pemandu investasi serta pelayanan prima di sektor kesehatan selain ditemukannya pelemahan terhadap penegakan peraturan. Dari berbagai peraturan yang sudah ditetapkan, Regulasi sosial paling lemah serta tidak adanya regulasi ekonomi. Regulasi yang berada di antara administrator pelayanan kesehatan di tingkat kabupaten sebagai titik lemah yang mengakibatkan pelayanan yang tidak efisien. Prakash mengaitkan regulasi kerangka kerja yang lemah di sektor kesehatan dengan waktu yang begitu lama serta kurangnya layanan kesehatan dasar di sebagian besar lembaga pelayanan kesehatan. (Athumani \& Minja, 2017) melakukan studi penelitian yang dilakukan di empat Otoritas Pemerintah Daerah Arusha dan menemukan bahwa kesadaran staf, kualifikasi staf dapat mempengaruhi tingkat kepatuhan dengan regulasi kerangka kerja yang berdampak pada pemberian pelayanan

Dengan adanya upaya yang dilakukan di Ghana menuju peningkatan peran praktik regulasi kerangka kerja keuangan publik serta kaitannya dengan efisiensi dalam pengelolaan anggaran dan pemberian layanan secara desentralisasi, maka artikel ini akan menjawab pertanyaan utama yaitu "Sejauh mana pengaruh peraturan yang mengatur kerangka kerja Manajemen Keuangan Publik dalam pemberian layanan oleh Majelis Distrik di Negara Ghana ?" Sehingga, permasalahan yang telah dijelaskan sebelumnya diatas ini menjadi dasar tujuan untuk mengeksplorasi pengaruh praktik regulasi keuangan publik pada pemberian layanan dalam konteks Majelis Distrik di Ghana.

\section{KAJIAN LITERATUR}

Teori New Public Management mengatakan bahwa pemerintah harus melakukan upaya untuk membangun kerangka hukum yang diperlukan, serta menetapkan aturan konstitusional yang diperlukan agar warga negara dapat meminta pertanggungjawaban kepada mereka yang mengimplementasikan kebijakan serta menangani anggaran publik. Pentingnya anggaran bagi pemerintah 
mungkin jelas, tetapi manajemen keuangan publik yang baik sering dianggap remeh. Sehingga, peran manajemen publik mengubah sistem manajemen keuangan pemerintah. Dalam model New Public Management, ditemukan adanya ketidakjelasan antara manajemen publik dan manajemen bisnis, di mana desakan yang dilancarkan pemerintah kepada sektor swasta. Perubahan birokrasi pemerintah yang menjadi unit bisnis strategis bersaing satu sama lain, dan masyarakat posisinya menjadi pengguna atau konsumen. Pejabat bukan hanya berpegang terhadap hukum secara yurisdiksi tertentu, tetapi pemerintah mengacu dari segi aturan pasar secara universal yang berkaitan tentang ekonomi dan efisiensi. Pembiayaan layanan pemerintah dihitung atas penetapan dasar harga dalam layanan publik. Potensi Manajemen Keuangan Publik baru dalam memberikan energi pada birokrasi yang kuat, mengindikasikan berbagai masalah. Pertama, tidak termasuk inti permasalahan pemerintah. Sebab pemerintah menanggung konsekuensi atas kegagalan pasar, atas hal-hal yang tidak memiliki keuntungan secara bisnis. Pemerintah mempromosikan program yang berorientasi pada kesejahteraan masyarakat umum dengan menyediakan barang yang dibutuhkan secara bersama dengan dibiayai dengan pajak. Kedua, birokrasi bertolak belakang dengan prinsip privatisasi, yang menciptakan adanya perbandingan menyimpang. Prinsip pemisahan kekuasaan pemerintahan yang demokratis, Check and Balance menjadi solusi reformasi dalam tata kelola pemerintahan. Ketiga, Manajemen Keuangan Publik yang baru secara terbuka mengangkat administratif dengan mengorbankan kekuasaan legislatif. Hal ini menciptakan akuntan secara efektif dengan pola pikir bisnis terhadap analis kebijakan yang berkaitan dengan pemahaman politik (Bovaird \& Löffle, 2009).

Manajemen Keuangan Publik ini mendasari semua kegiatan pemerintah yang mencakup tentang mobilisasi pendapatan; alokasi dana ini untuk berbagai kegiatan; pengeluaran; dan akuntansi untuk dana yang dihabiskan. Meskipun Manajemen Keuangan Publik belum berjalan secara efektif, sebagian besar akan mengalami banyak konsep dan proses dalam kehidupan mereka secara professional. Pegawai negeri akan berpartisipasi dalam langkah-langkah siklus anggaran ketika mereka menganggarkan suatu program, menaikkan suatu belanja, meninjau laporan pengeluaran atau menyiapkan dokumen untuk pemeriksaan audit eksternal (Simson et al., 2011)

Lima prinsip telah muncul yang mencerminkan praktik yang baik dalam pekerjaan PFM. Prinsip-prinsip yang tercermin dalam panduan berikut ini, yaitu : (1) Pekerjaan PFM harus memfasilitasi dan mendorong kepemimpinan negara dalam menetapkan/mengelola strategi dan rencana aksi reformasi PFM; (2) Pekerjaan diagnostik Manajemen Keuangan Publik harus dilakukan secara terpadu dan terkoordinasi, dengan memanfaatkan kompetensi yang berbeda dari setiap negara Manajemen Keuangan Publik dan lembaga donor lainnya, dengan waktu dan ruang lingkup yang ditentukan sesuai kebutuhan negara; (3) Manajemen Keuangan Publik harus mendukung pelaksanaan reformasi PFM dan peningkatan kapasitas yang menambah nilai pada anggaran Pemerintah dan proses reformasi, dan harus diselaraskan dengan siklus pengambilan keputusan Pemerintah; (4) Manajemen Keuangan Publik diurutkan berdasarkan prioritas yang disepakati, dan dibangun di atas pendekatan yang terkoordinasi (5) Manajemen Keuangan Publik harus 
dikaitkan dengan kerangka kerja pemantauan dan evaluasi yang kuat, yang dengan jelas mengartikulasikan keuntungan dalam kinerja sistem PFM yang dicari atau dicapai (World Bank, 2011).

Regulasi Kerangka kerja Manajemen Keuangan Publik lain yang relevan adalah teori efisiensi alokatif. (Anderssen \& Isaksen, 2003) berpendapat bahwa, struktur regulasi dan tata kelola yang baik dari manajemen keuangan publik harus diterapkan untuk dapat memastikan pertumbuhan ekonomi dan program jangka panjang pengentasan kemiskinan. Pendekatan efisiensi alokatif menyatakan bahwa adanya kebutuhan terhadap pengawasan yang tepat untuk memastikan bahwa sumber daya dapat dimobilisasi, didistribusikan, serta digunakan secara adil di seluruh daerah dalam memberikan pelayanan yang menjadi kebutuhan primer warga negara. (Mandl et al., 2008) memberikan pendapat mereka bahwa efisiensi alokatif secara teknis merupakan peran penting untuk dapat memastikan bahwa sektor publik memberikan hasil pelayanan yang diperlukan secara efektif mengingat ketersediaan sumber daya yang langka.

\section{METODE PENELITIAN}

Pada analisis dalam penulisan ini, penulis menggunakan metode kualitatif dengan pendekatan analisis deskriptif yang digunakan sebagai metode untuk menggambarkan atau menganalisis suatu hasil penelitian tetapi tidak digunakan untuk membuat suatu kesimpulan yang lebih luas. Teknik pengumpulan data yang dilakukan oleh penulis berdasarkan atas hasil penelaahan buku, jurnal, artikel ilmiah, dan berbagai laporan setiap tahunnya dari berbagai badan atau lembaga instansi yang memiliki wewenang sesuai dengan fenomena yang ingin dibahas oleh penulis. Dari beberapa sumber tersebut kemudian penulis menganalisis sesuai dengan variabel yang akan diangkat oleh penulis. Sehingga, output yang dihasilkan akan menjawab pertanyaan utama diatas tentang pengaruh peraturan terkait kerangka kerja yang akan dibangun dalam Manajemen Keuangan Publik untuk memberikan layanan dengan konteks disini Majelis Distrik di Negara Ghana.

\section{HASIL DAN PEMBAHASAN}

Pembahasan ini akan mengemukakan hasil pada regulasi kerangka kerja Manajemen Keuangan Publik dan pengaruhnya terhadap penyediaan layanan Majelis Distrik di Ghana. Studi konseptual pada regulasi Kerangka kerja akan memperlihatkan bahwa regulasi kerangka kerja Manajemen Keuangan Publik ini sebagai salah satu komponen manajemen anggaran publik yang akan dapat berdampak pada pemberian pelayanan.

1) Ketersediaan Regulasi Kerangka Kerja Manajemen Keuangan Publik Majelis Distrik

Pembahasan ini dimulai dengan bagaimana tolak ukur terhadap kesadaran hukum yang mengatur manajemen anggaran publik. Persentase menunjukkan bahwa sebesar 60,5 persen (\%) pejabat Majelis Distrik menyatakan bahwa mereka mengetahui akan regulasi atau undang undang yang mengatur manajemen keuangan di Majelis Distrik. Tetapi, 39,5 persen (\%) para pejabat Majelis Distrik tidak mengetahui tentang undang-undang tersebut. Hasil tersebut menunjukkan bahwa Pemerintah Ghana memiliki Undang-undang serta instrumen legislatif yang digunakan dan relevan untuk mendesentralisasi lembaga lain yang bertujuan mengatur pengelolaan anggaran publik. Pemerintah Ghana menyadari bahwa Undang-undang dan regulasi ini mengetahui adanya regulasi yang mengatur 
pengganggaran tersebut meskipun beberapa dari mereka belum memahami serta mempelajari dokumen-dokumen tersebut secara komprehensif. masingmasing majelis distrik memiliki regulasi dalam mengatur yurisdiksi dan kegiatan spesifik mereka. Namun, hasilnya menunjukkan bahwa banyaknya Anggaran Rumah Tangga majelis distrik tidak dirperbaharui. Sehingga disini jelas bahwa perlu adanya peninjauan serta memperbaharui isi dari ART mereka. Bahkan mereka pun tidak memiliki klausul penegakan hukum yang kuat untuk mendukung kinerja mereka.

Berdasarkan rating Regulasi

Framework Governing Manajemen Keuangan
Publik, sebesar 68,4 persen pejabat Majelis Wilayah menilai kerangka peraturan yang mengatur pengelolaan keuangan publik dinyatakan efisien. Laporan (World Bank, 2011) tentang sistem manajemen keuangan publik terdesentralisasi pada negara Ghana yang mencatat bahwa badan yang terdesentralisasi di Ghana memiliki kerangka hukum dan peraturan yang solid yang menetapkan struktur penganggaran dan akuntabilitas yang tepat. Sebesar 31,6 persen jawaban responden mengindikasikan bahwa regulasi kerangka kerja atas pengelolaan keuangan publik tidak efisien.

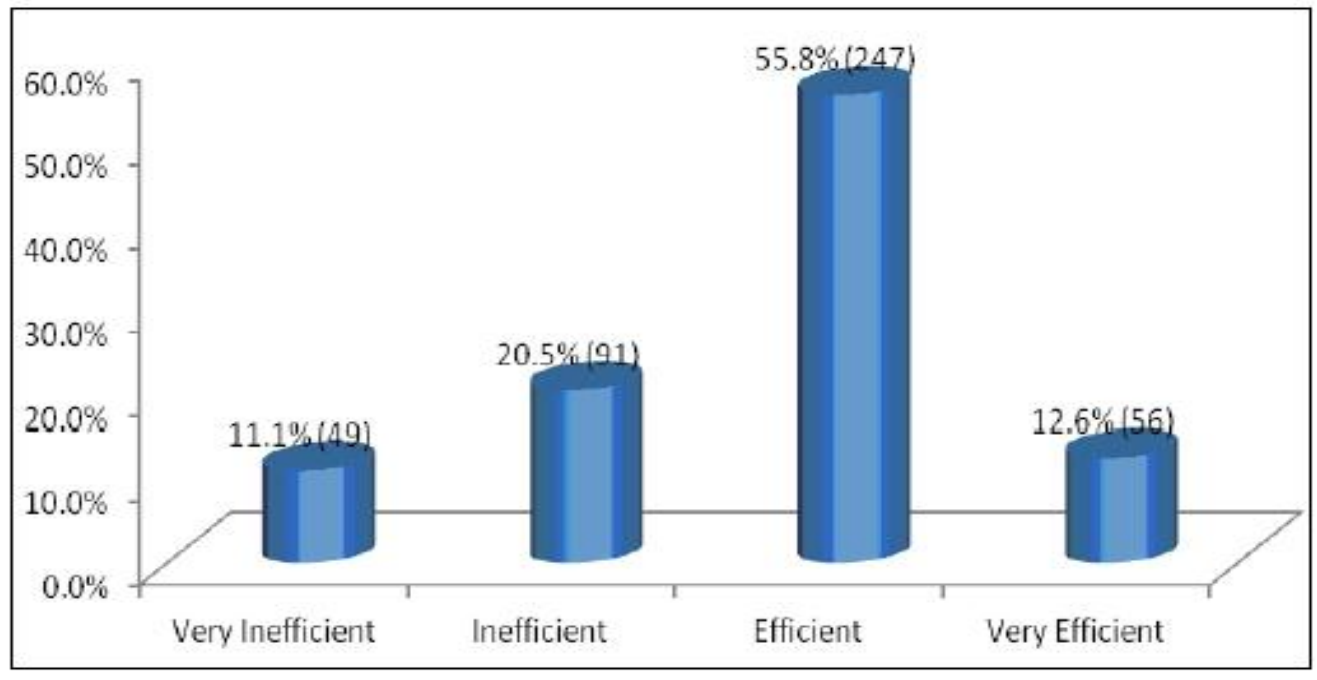

Gambar 1.

Rating pada Regulasi Framework Governing Manajemen Keuangan Publik Sumber : (Scott, 2018)

Hasil tersebut menyatakan bahwa anggaran rumah tangga yang sangat baik tetapi perlu ada peninjauan serta pembaruan didalam Anggaran Rumah Tangga tersebut. Selain itu, Masyarakat juga disini harus diberikan sosialisasi tentang apa saja isi regulasi serta keterkaitan dengan pengelolaan keuangan publik yang berimbas pada penyediaan pelayanan. Majelis distrik di wilayah mereka tidak mempunyai anggaran rumah tangga yang lebih baik dalam mengatur manajemen keuangan publik mereka. Sehingga efeknya adalah banyaknya regulasi yang dilanggar dengan cara impunity atau secara jelasnya merupakan pemberian pembebasan atau pengecualian dari para pejabat pemerintah sehingga pada akhirnya mereka membangun gedung di tempat yang tidak 
sah dan tidak disertakan Izin Mendirikan Bangunan.

Pandangan seperti itu jelas akan timbul kekhawatiran serta persepsi masyarakat terkait dalam penyediaan layanan, sementara segi sarana dan prasarana belum memenuhi prosedur pada selayaknya. Seharusnya, Majelis Distrik yang ada di Negara Ghana dapat memastikan bahwa prosedur yang sudah ditetapkan sebelumnya dinyatakan berhasil. Temuan tersebut mirip dengan yang dilakukan oleh (Zhou, 2012) bahwa regulasi kerangka kerja saja tidak cukup dalam menyediakan sebuah pelayanan yang efektif, tetapi adanya kepatuhan terhadap regulasi yang telah dirancang menjadikan hal penting. Sehingga, dalam regulasi pengelolaan keuangan publik yang efektif adanya sebuah panduan atau petunjuk dengan bertujuan untuk diarahkan sesuai dengan paradigma New Public Management.

2) Hubungan Antara Regulasi Kerangka Kerja Dan Pemberian Layanan

Berdasarkan pada Tabel 1 menunjukkan bahwa 64,9 persen dinyatakan setuju dengan adanya penjelasan bagaimana regulasi kerangka kerja dalam mengelola keuangan publik yang nantinya akan digunakan untuk memberikan pelayanan yang lebih baik.

Tabel 1.

Persentase Regulasi Kerangka Kerja dalam Pemberian Pelayanan

\begin{tabular}{|lccccc|}
\hline Regulasi Kerangka kerja dan pemberian layanan & $\mathbf{1}$ & $\mathbf{2}$ & $\mathbf{3}$ & $\mathbf{4}$ & $\mathbf{5}$ \\
\hline $\begin{array}{l}\text { Peraturan dan regulasi membantu mencegah } \\
\text { pemborosan dan korupsi }\end{array}$ & 3.8 & 6.8 & 14.0 & 26.5 & 48.8 \\
\hline $\begin{array}{l}\text { Adanya sanksi dan hukuman bagi mereka yang } \\
\text { menentang }\end{array}$ & 3.6 & 9.0 & 14.0 & 32.4 & 40.9 \\
\hline $\begin{array}{l}\text { Klarifikasi bagaimana seharunya keuangan publik } \\
\text { digunakan untuk pemberian layanan yang lebih } \\
\text { baik }\end{array}$ & 0.7 & 2.5 & 9.0 & 22.9 & 64.9 \\
\hline
\end{tabular}

Sumber : (Scott, 2018)

Penemuan ini sesuai dengan penelitian (Prakash, 2015) yang mengatakan bahwa seharusnya badan legislatif bisa memainkan peran pengawasan dalam pengelolaan keuangan publik dengan memastikan bahwa mereka memiliki peraturan serta sistem yang pas bagaimana mengarahkan pengelolaan dana publik dalam rangka mencegah korupsi dan penyalahgunaan anggaran. Jika terjadi hal seperti korupsi, suap, serta penyalahgunaan anggaran publik, Lembaga Peradilan dapat berperan dalam menjatuhkan hukuman yang tepat apabila mereka yang berpartisipasi dalam pengelolaan dana publik dinyatakan bersalah. Sehingga, dampaknya pada akuntabilitas publik dalam Peranan tersebut sehingga dapat dipastikan bahwa keuangan publik diterapkan sesuai dengan kepentingan publik.

Selanjutnya, 75,3 persen bahwa regulasi dapat membantu mencegah pemborosan anggaran serta adanya tindakan korupsi. Penelitian (Carney, 2011) adanya tingkat kepatuhan dalam menjalankan peraturan serta adanya punishment yang diberikan bagi mereka yang tidak mematuhi aturan yang ditetapkan. Sehingga, dampaknya akan terlihat bahwa peraturan yang dirancang membantu mengendalikan penyalahgunaan serta pemborosan anggaran publik. Dan 73,3 persen setuju bahwa regulasi kerangka 
kerja ditegakkan melalui sanksi dan hukuman yang menentangnya. Ketika penerapan regulasi kerangka kerja ditetapkan karena adanya ketidakpatuhan terhadap peraturan yang dirancang maka suatu tindakan sanksi harus diberikan kepada pelaku penyalahgunaan anggaran. Jika hal tersebut terlaksana, dampak dari hal tersebut merupakan suatu tindakan dalam melakukan penegakkan peraturan untuk mengelola keuangan publik yang memberikan efek jera kepada para pelaku tentunya.

3) Tingkat Pengaruh Regulasi Kerangka Dalam

Pemberian Pelayanan
Pembahasan pada bagian ini untuk mengetahui sejauh mana regulasi kerangka kerja manajemen keuangan public dapat memberikan pengaruh pada layanan yang nantinya pada implementasinya baik itu nantinya menghambat atau mempermudah fasilitas pelayanan yang diberikan dapat terukur. Hasilnya seperti yang terlihat pada tabel 2 bahwa 65,9 persen para pejabat majelis distrik menunjukkan bahwa peraturan kerangka kerja yang mengatur tentang pengelolaan dana berpengaruh dalam pemberian pelayanan.

Tabel 2.

Tingkat Pengaruh Regulasi Kerangka Kerja dalam Pemberian Pelayanan

\begin{tabular}{|ccc|}
\hline Tingkat Pengaruh & Frekuensi & Persentase (\%) \\
\hline Sangat Rendah & 12 & 2.7 \\
\hline Rendah & 42 & 9.5 \\
\hline Sedang & 97 & 21.9 \\
\hline Tinggi & 132 & 29.9 \\
\hline Sangat Tinggi & 159 & 36 \\
\hline Total & 442 & 100 \\
\hline
\end{tabular}

Sumber : (Scott, 2018)

Temuan tersebut memiliki pengaruh yang kecil dalam pemberian layanan. Dikarenakan, regulasi yang ada saat ini tidak berurusan dengan para pejabat majelis wilayah yang terbukti terlibat dalam korupsi sebagai penyebab utama buruknya pemberian layanan. Sehingga, berdasarkan analisis saya, sebuah aturan mungkin diperlukan sebagai sebuah pegangan atau komitmen yang tingkat kredibilitasnya dapat dipercaya dalam menghadapi kesalahan atas pengelolaan dana publik serta memastikan pemberian pelayanan yang efektif serta efisien.

Dalam praktik peraturan kerangka kerja manajemen keuangan publik di
Majelis Distrik tidak berpengaruh atas pemberian layanan. Artinya bahwa berbagai temuan yang telah digambarkan dalam kerangka kerja konseptual tidak berpengaruh pada pemberian pelayanan. Dampak konseptualnya bergantung pada peraturan yang diberlakukan secara efektif yang mengakibatkan adanya sanksi dan hukuman sebagai penunjang dalam penegakan hukum, terutama bagi mereka yang menyalahgunakan ataupun tidak mematuhi aturan. Ada beberapa titik lemah dalam aturan yang mengatur tentang manajemen keuangan public di Majelis Distrik Ghana karena peraturan ini tidak 
diberlakukan secara efektif sebagai cara untuk inefisiensi anggaran publik.

\section{PENUTUP}

Kesimpulan yang dapat diambil bahwa peraturan kerangka kerja manajemen keuangan publik berpengaruh pada pelayanan yang diberikan oleh Majelis Distrik di Ghana. Namun, penelitian ini ditemukan bahwa peraturan kerangka kerja manajemen keuangan publik memiliki efek positif tetapi tidak signifikan dalam memberikan pelayanan. Ada instrument legislative dalam mengatur desentralisasi serta manajemen keuangan di setiap Majelis Distrik. Peraturan kerangka kerja menjelaskan bagaimana anggaran publik digunakan untuk memberikan pelayanan yang lebih baik. Peraturan tersebut dirancang bertujuan untuk membantu mengurangi pemborosan anggaran serta mencegah tindak pidana korupsi. Sebagian besar pejabat Majelis Wilayah tahu tentang undang-undang yang mengatur pengelolaan dana di Majelis Wilayah. Adanya peraturan kerangka kerja ini hanya memiliki sedikit pengaruh pada pemberian layanan karena tidak ditegakkan secara tepat. Regulasi belum dapat menangani dengan tegas lingkungan pejabat Majelis Wilayah yang ditemukan terlibat dalam tindak korupsi yang menjadi penyebab utama buruknya pelayanan yang diberikan kurang maksimal. Berbagai aturan yang telah ada perlu ditinjau serta diperbarui. Masyarakat membutuhkan sosialisasi tentang anggaran rumah tangga terkait pengelolaan dana publik yang berorientasi pada pelayanan publik.

Saran terkait penulisan ini yaitu dari tingkatan Para pejabat Majelis Distrik, lembaga eksekutif serta beberapa direktur yang terkait tentang manajemen keuangan publik harus mengadakan kegiatan seperti sosialisasi tentang Undang-Undang Manajemen Keuangan Publik, Kebijakan yang harus diterapkan seperti apa, standar yang harus dicapai seperti apa. Hal tersebut tentu akan membantu pemahaman staf yang ada didalamnya sehingga mereka dapat memastikan serta menjalankan aspek hukum yang telah ada serta menghilangkan batasan-batasan dalam rangka memfasilitasi pemberian pelayanan di setiap wilayah yang ada di Ghana. Wilayah majelis juga harus memperkuat serta meningkatkan tingkat teknologi yang sesuai dengan Manajemen Keuangan Publik sebagai orientasi dalam memberikan pelayanan yang lebih baik.

Bidang dokumentasi serta bidang hukum dari Majelis Distrik juga harus diperkuat untuk dapat memastikan bahwa bidang tersebut memegang tanggung jawab dalam pengawasan tata kelola hukum serta sistem peraturan Majelis Distrik. Adanya tingkat lanjut atas implementasi anggaran rumah tangga serta reformasi legislatif untuk memperluas basis pendapatan Wilayah Majelis. Sehingga penerapan mekanisme aturan memungkinkan untuk melakukan pembiayaan obligasi sebagai fitur utama dalam kredit pasar lokal. Model pembiayaan obligasi yang dihalangi untuk suatu proyek-proyek tertentu masih bisa dieksplorasi oleh Majelis Distrik Ghana.

Pada tingkatan pusat, amandemen peraturan perundang-undangan yang relevan serta konstitusional agar dapat memastiakn porsi yang lebih besar dari District Assemblies Common Fund (DACF). Aturan yang diperlukan juga agar nantinya dapat memastikan transfer anggaran yang efektif dan tepat waktu dari Pemerintah Pusat ke Majelis Wilayah. Perlu adanya konsolidasi undang-undang manajemen keuangan untuk memastikan hukuman yang akan dijatuhlan lembaga penegakan hukum dalam menerapkan sanksi terhadap mereka yang terlibat dalam penyalahgunaan keuangan publik di tingkat Majelis Distrik. Lembaga penegak hukum 
perlu diberikan pelatihan secara bertahap untuk menuntut serta mengembalikan keuangan publik yang telah dikorupsi untuk pemberian layanan yang lebih baik di setiap wilayah desentralisasi pemerintah.

Upaya yang harus dilakukan yaitu dengan peraturan kerangka kerja serta undang-undang baik dari tingkatan pusat hingga ke setiap wilayah majelis dibuat sesederhana mungkin serta terstandarisasi. Peraturan kerangka kerja seperti itu memungkinkan adanya adaptasi terlebih dahulu di setiap Majelis yang berbeda. Dampaknya, adanya informasi tambahan serta sistem manajemen oleh setiap Majelis Wilayah bila diperlukan.

Stakeholder terkait diharapkan mampu mendorong masyarakat sipil dalam rangka meningkatkan kesadaran tentang peraturan kerangka kerja Manajemen Keuangan Publik baik secara langsung maupun lewat media sosial. Masyarakat didorong untuk meningkatkan pengetahuan mereka tentang peraturan kerangka kerja manajemen keuangan publik, praktik pengelolaannya, serta pelayanan yang secara langsung memiliki keterikatan dengan kehidupan mereka. Outputnya adalah, mereka dapat secara aktif menuntut akuntabilitas dari para pemimpin yang telah mereka pilih sebagai wujud memberikan pelayanan yang lebih baik dengan dampaknya akan terlihat pada peningkatan kualitas hidup.

\section{DAFTAR PUSTAKA}

Anderssen, G., \& Isaksen, J. (2003). Best Practice In Building African Capacity For Public Expenditure Management (Issue November).

Athumani, H. ., \& Minja, G. . (2017). The Influencing Factors Of Procurement Regulatory Compliance By Tanzanian Local Government Authorities: Case Of Arusha Region Haruna I. Athumani
And Goodluck J. Minja. Journal, European Chain, Supply Vol, Management Centre, European Uk, Development, 5(3), 1-12.

Bovaird, T., \& Löffle, E. (2009). Public Management And Governance. In Public Management And Governance (Vol. 2).

Buertey, I. J. T., Miezah, A. K., \& Kumi, T. A. (2014). Delays To Large Construction Projects In Ghana: A Risk Overview. Journal of Civil Engineering And Architecture, 8(3), 367-377.

Carney, M. (2011). Influence Of Organizational Culture On Quality Healthcare Delivery. International Journal Of Health Care Quality Assurance, 24(7), 523-539.

Https://Doi.Org/10.1108/0952686111 1160562

Hendriks, C. J. (2013). Integrated Financial Management Information Systems: Guidelines For Effective Implementation By The Public Sector Of South Africa. SA Journal Of Information Management, 14(1), 1-9. Https://Doi.Org/10.4102/Sajim.V14i1. 529

ICPAK. (2017). Public Financial Management ( PFM ) Conference PFM Reforms In Africa April 2017 Agenda. April.

Jonah, C. M. P. (2014). Spatial Dimensions Of Health Inequities In A Decentralised System: Evidence From Ghana [University Of Western Cape]. Http://Etd.Uwc.Ac.Za/Xmlui/Handl e/11394/4295

Jordaan, J., \& Fourie, D. (2007). Contextualising The Measurement Of Governance In Public Financial Management. Journal of Public Administration, 42(5), 35-45.

Kopits, G. (2011). Independent Fiscal Institutions: Developing Good Practices. Oecd Journal On Budgeting, 
11(3),

1-18.

Https:/ / Doi.Org/10.1787/Budget-11-

$5 \mathrm{~kg} 3 \mathrm{pdgcpn} 42$

Lee, R.D., Johnson, R. . (1998). Public Budgeting System. Aspen Publisher.

Lynn, L. E., Heinrich, C. J., \& Hill, C. J. (2001). A Logic For Governance Research. In Improving Governance: A New Logic For Empirical Research (Pp. 1739). Georgetowne University Press.

Mandl, U., Dierx, A., \& Ilzkovitz, F. (2008). The Effectiveness And Efficiency Of Public Spending (E. Commision (Ed.); Vol. 2, Issue

2). Http://Ec.Europa.Eu/Economy_Finan ce/Publications.

Https:/ / Doi.Org/10.2765/22776

Moyo, J. (2011). The Challenges Of Public Administration In Zimbabwe Today. $\mathrm{Http} / /$

Www.Newzimbabwe.Com/Blog.

Ohman, M. (2012). Political Finance Regulations Around The World. An Overview of The International IDEA Database. International Institute For Democracy And Electoral Assistance.

Prakash, G. (2015). Steering Healthcare Service Delivery: A Regulatory Perspective. International Journal of Health Care Quality Assurance, 28, 173192.

Https:/ /Doi.Org/10.1108/0952686071 0819440

Samihah Khalil. (2012). Fiscal Planning And Local Government Administration In Nigeria: The Quest For Sustainable Rural Development. African Journal Of Business Management, 6(9), 3482-3489.
Https:/ / Doi.Org/10.5897/Ajbm11.215 4

Santiso, C. (2015). Why Budget Accountability Fails? The Elusive Links Between Parliaments And Audit Agencies In The Oversight Of The Budget. Revista De Economia Politica, 35(3), 601-621. Https://Doi.Org/10.1590/010131572015v35n03a12

Scott, G. K. (2018). Implications Of Public Financial Management Regulatory Framework On Service Delivery : Reflections Of Ghana ' S District Assemblies. Journal Of Public Policy, Vol. 4 No.(January). Https://Www.Researchgate.Net/Publ ication/322765903

Simson, R., Sharma, N., Aziz, I., \& Odi. (2011). A Guide To Public Financial Management Literature: For Practitioners In Developing Countries. ODI Publication, December, 1-39. Https://Www.Odi.Org/Sites/Odi.Or g.Uk/Files/Odi-Assets/PublicationsOpinion-Files/7542.Pdf

World Bank. (2011). Strengthened Approach To Public Financial Management Reform. Public Expenditure Working Group. Http://Www1.Worldbank.Org/Public sector/Pe/Strengthenedapproach/

Zhou, G. (2012). Public Administration In Zimbabwe A Framework Approach. Journal Of Public Administration And Governance, 2(2), 132. Https://Doi.Org/10.5296/Jpag.V2i2.2 045 